\title{
The Influence of the Augmented Reality Application on Students' Performances in Ottoman Turkish Readings
}

\author{
Mehmet Fatih Özcan ${ }^{1, *}$, Adem Özkan², Nurullah Şahin ${ }^{1}$ \\ ${ }^{1}$ Department of Social Sciences and Turkish Education, Faculty of Education, Ağrı İbrahim Çeçen University, Turkey \\ ${ }^{2}$ Department of Computer Technology and Programming, Vocational School, Ağrı İbrahim Çeçen University, Turkey
}

Copyright $\bigcirc 2017$ by authors, all rights reserved. Authors agree that this article remains permanently open access under the terms of the Creative Commons Attribution License 4.0 International License

\begin{abstract}
The use of Augmented Reality Technologies, which has been developed in order to enrich the environment of education and training and provide permanent learning, has been increasing day by day. In this sense, it is important to analyze the use of augmented applications in education and training environments. In this study, We have aimed to determine students' academic success levels and their satisfactions through the use of augmented applications in Ottoman Turkish reading which students have difficulties learning. For this purpose, an experimental study has been conducted with 60 students, 30 from experimental and 30 from control group, studying in the department of Turkish studies in the faculty of Education Faculty of Ağrı İbrahim Çeçen University. The experimental and control groups have been chosen at random. The study has lasted totally 4 weeks- 1 weeks as pilot 3 weeks as application. The academic success test, that has been prepared to assess students' academic success, prepared by experts and covered 7 weeks, has been applied as the pre-test in the beginning and final test at the end of the process. Additionally, a semi structured interview has been carried out with randomly chosen students from the experimental group. The views of students about the use of augmented reality in Ottoman Turkish readings have been taken into consideration and the level of their satisfaction has been determined. After analysis of the obtained data, it has been understood that there is a meaningful difference between the average academic success grades of the experimental and control groups. The analysis of the findings, obtained by the semi-structured interview, are still continuing. According to the first findings, it has been observed that the use of augmented reality in education and training environment has positive contributions to student success and satisfaction.
\end{abstract}

Keywords Ottoman Turkish Augmented Reality Teaching Technologies

\section{Introduction}

People have used different methods throughout history in accessing information, which has an important position in the developing world (Bedük \& Balcilar, 2009). These methods differed with the progress of the technology. Especially today, the widespread use of internet and mobile technologies has become one of the most effective methods of accessing information. Conducting studies on the use of these technologies, which are used to access the information, in the educational environment and in education are becoming more important every day (Akbaş, 2011; Liu, Tan, \& Chu, 2010). On looking at the studies done on the use of Internet and mobile technology in education, it turns out that the learning content needs to be related to real life in order to increase learning efficiency and effectiveness (Klopfer \& Squire, 2008). Augmented Reality (AR) technology, which has recently become increasingly used, makes learning to be permanent and fun by associating learning content with real life in educational settings (Wu, Lee, Chang, \& Liang, 2013).

$\mathrm{AR}$ is defined as a simultaneous display of two-dimensional and three-dimensional state of the real objects which has been created as three-dimensional in computer environment with camera and special software (Bujak, et al., 2013, Aziz, Aziz, Yusof, \& Paul, 2012). In another definition; AR is to display an object which is displayed on a computer or mobile device as a real object on the screen to the user by transforming it to virtual image (Cakir, Solak, \& Tan, 2015). AR is a technology used in the digital display of printed materials and objects. When you look at the printed material through the mobile device, tablet or computer camera, the digital content previously integrated into that material is displayed as the real to the user. Due to this feature, it is inevitable that $A R$ applications take place in education and training processes (Liu, Tan, \& Chu, 2010). 
AR systems have two basic features. These are (1) the combination of real and virtual objects in a real environment, and (2) synchronous and interactive working of virtual objects (Azuma, et al., 2001). Thanks to these features, many studies are being carried out on the use of AR technologies in fields such as mobile communication, advertising, publishing, tourism and education. For example, Çakır, Solak and Tan (2015) examined the effect of the use of AR technology in English vocabulary teaching on student performance and they found that the use of AR technology in education contributed positively to student performance.

Although AR technology is not yet fully utilized in our country and people are not aware of it, it is on its way to become one of the most popular technologies of our future (Yildiz, 2012). When we look at the work done in our country related to AR, it is seen that AR technology in general has been studied on its importance, its usage areas and its integration into education and training environments. For example, Çetinkaya and Akçay (2013) gave examples of increased reality practice used in educational environments and emphasized the effect of increased reality on teaching and learning. In another study, it was observed that Turul and Yilmaz (2012) tried to provide an application program developed using computer programming language $(\mathrm{C})$, Unity $3 \mathrm{D}$ game application and qr-code system to display a non-existing object in real environment on the screen, as if it really existed. Demirer and Erbaş (2015) in their study titled "Examining Mobile Augmented Reality Applications and Evaluation of them in terms of Education", examined some AR applications and evaluated them educationally. As a result of their evaluation, it was seen that mobile they recommended the use of AR applications in the educational environment.

Sarikaya aimed to determine the use of AR learning material to test of the students' success, misconceptions and course attendance, and to determine the students' views on the AR learning material in his Ph.D. thesis titled "Increased Reality Applications' Academic Achievement, Misconceptions and Impact on Participation of Students in Increased Reality Practices" in 2015. According to the results of the research, it was concluded that the use of AR material affects student success positively, eliminates misconceptions and increases student participation. $\mathrm{He}$ also stated that the students had expressed that the AR materials embody abstract information, help them understand the topics and increase their participation in the class.

AR is a new technology that is used to provide students to look at the contents of the course from a different perspective and to increase their interest to the course (Cakir, Solak, and Tan 2015). It is thought that this technology will be beneficial for the students to use in the Ottoman Turkish lesson which is one of the most challenging lessons for the students. In order to master Ottoman Turkish, it is necessary to know Arabic alphabet well, Arabic and Persian phrases, unified structure and vocabulary, and to understand modern Turkish grammar in detail (Gümüşkılıç, 2009). To memorize the letters of the alphabet, to see and to read that the letters follow each other and become words is the first step to printed text called press printed, that is the simplest Ottoman Turkish language.

If we look at the definitions of Ottoman Turkish, it is defined as the Turkish written in Arabic alphabet, containing Arabic and Persian words intensely in Ottoman Empire until 1928 (Develi, 2009). During this period, Ottoman Turkish had been used both in official correspondences of the state and in different branches of science, as well as in literary and artistic environments. Thus, it had become a culture language with the addition of mainly Turkish and then Arabic and Persian languages and Western languages later (Parlatır, 2010). Professor Dr. Faruk K. Timurtaş defined it as "Ottoman Turkish is our historical literature language "(Kaya, 2013). Ottoman Turkish is a unique language developed by Turks for centuries. It was fed from both Arabic and Persian, but become neither, the new Turkish generations should be able to understand Ottoman Turkish so that they can build bridges between the future and the past! Ottoman Turkish is not understood as a separate language like French and Russian, it is the Turkish written in Arabic letters. It is not a language. It is jargon. There was a German language spoken in Vienna, in the palace and in the office, but you never heard a language called Hapsburg Deutch. Every language will undergo some changes from the century to century, but it is not needed to mention a different language. Eventually, it is the language that our grandmother and our grandfather exchanged letters with it (Ortayli, 2014). When the studies on the Ottoman Turkish are examined, the study of Özkan and Şahbaz (2011) titles as "Turkish Language Teachers' Opinions about the Functioning of the Major Area Courses" was found. The universe and sample of the study constitute 116 pre-service teachers who are studying at the Department of Turkish Education at 12 universities. In this study, it was determined that pre-service Turkish Language teachers did not find Ottoman Turkish lessons functional only among theoretical courses within the scope of 'major area courses', they evaluated the other 16 lessons as functional. Gümüşkıliı̧ (2009) has a study titled "Ottoman Turkish Education in Turkish Language and Literature Departments". In this study, 8 universities in Turkey were taken as a sample and the Ottoman Turkish which is being taught in the Turkish Language and Literature departments of these universities was evaluated and some recommendations have been made about what needs to be done so that these lessons can be given to the students more efficiently.

Today's students are growing up in the technology of digital age. In this respect, the level of readiness of the students at the point of using the AR technologies is at highest level. This reveals the necessity for educators to 
include AR applications in the classroom. In this respect, the aim of this study is to determine the effect of the use of AR technology on the academic success of the students and their motivation levels about AR material in the Ottoman Turkish teaching. In the direction of this aim, this study is seeking answers to the following research questions;

1. Is there a difference in terms of Ottoman Turkish vocabulary learning of students in the experimental and control groups?

2. What is the motivation of the experimental group students towards the material developed by the AR technology?

\section{Method}

\subsection{Research Design}

Experimental method is used to determine the responses of the subjects to the variables whose effect is investigated and which is applied on the subjects under certain circumstances and to determine cause and effect relationships between the variables (Altunışık, Coşkun, Bayraktaroğlu, \& Yıldırım, 2010). In this study, quasi-experimental design was used as a quantitative research method. The semi-experimental design is used in cases where the experimental and control groups are not determined randomly. In this study, it is aimed to investigate the effect of the activities prepared by AR technology on students' academic success. For this purpose, academic achievement test was used to determine the academic achievement of the students and material motivation questionnaire prepared according to the ARCS (Attention-Relevance-Confidence-Satisfaction) motivation model was used to determine the motivation of the experimental group for the material developed with AR technology.

\begin{tabular}{|c|c|c|c|}
\hline Groups & Pre-test & Procedure & Post-Test \\
\hline Experimental & $\begin{array}{c}\text { Academic } \\
\text { Achievement T. }\end{array}$ & AR Applications & $\begin{array}{c}\text { Academic } \\
\text { Achievement T. } \\
\text { Motivation } \\
\text { Questionnaire }\end{array}$ \\
\hline Control & $\begin{array}{c}\text { Academic } \\
\text { Achievement T. }\end{array}$ & $\begin{array}{c}\text { Current teaching } \\
\text { method }\end{array}$ & $\begin{array}{c}\text { Academic } \\
\text { Achievement T. }\end{array}$ \\
\hline
\end{tabular}

Experimental Design Applied in Research

\subsection{Study Group}

The study was carried out with 60 freshman students in the Department of Turkish Education in the Faculty of Education of İbrahim Çeçen University of Ağrı in the spring semester of 2016-2017 academic year. The class was divided into two, 30 students in experimental group and 30 students in control group with non-random sampling method. The distribution of the students in the experiment and control groups in terms of gender is indicated in Table-1.
Table 1. The distribution of the students in the experiment and control groups in terms of gender

\begin{tabular}{|c|c|c|c|c|}
\hline Group & $\mathbf{N}$ & Male & Female & Total \\
\hline \multirow{2}{*}{ Control } & $\mathrm{n}$ & 18 & 12 & 30 \\
\cline { 2 - 5 } & $\%$ & 60 & 40 & 100 \\
\hline \multirow{2}{*}{ Experimental } & $\mathrm{n}$ & 16 & 14 & 30 \\
\cline { 2 - 5 } & $\%$ & 53,3 & 46,7 & 100 \\
\hline \multirow{2}{*}{ Total } & $\mathrm{n}$ & 34 & 26 & 60 \\
\cline { 2 - 5 } & $\%$ & 56,7 & 43,3 & 100 \\
\hline
\end{tabular}

In the experimental group, there are 30 students, $46.7 \%$ female and $53.3 \%$ male and in the control group, there are 30 students, $40 \%$ female and $60 \%$ male.

\subsection{Data Collection Tools}

Academic Achievement Test: In order to determine the academic success of the students, an academic achievement test consisting of 20 multiple choice questions was formed in the direction of the Ottoman vocabulary, pronunciation and the meaning of the words, and Ottoman spelling of Turkish words. The prepared test was presented to two field experts and two linguists, and necessary corrections were made and the final form of the test was made according to feedback of the experts. At the beginning of the study, the test was applied as pre-test to the experimental and control groups, and it was applied as the final test at the end of the study.

Material Motivation Questionnaire: The Material Motivation Questionnaire was used to determine the motivation of university students about the Ottoman vocabulary teaching application prepared by AR technology. The effect of the teaching materials on the student motivation questionnaire developed by Keller (1987) according to ARCS motivation model was adopted into Turkish by Kutu and Sözbilir (2011) and the reliability and validity studies of the questionnaire were done. According to this study, the questionnaire consists of 24 items in a two-factor structure (attention-compliance and trust-satisfaction). The reliability of the questionnaire (Cronbach Alpha) internal consistency coefficient was 0.83 for the total questionnaire, and 0.79 and 0.69 for sub-factors, respectively. The questionnaire is a five-point Likert type rating scale and it was rated as "Strongly Disagree (1)", "Disagree (2)", "Neither (3)", "Agree (4)" and "Strongly Agree (5)".

\subsection{Study Process}

The study lasted four weeks, one week pilot and three weeks of practice. The study was carried out in two different groups, experimental and control groups. In practice, Ahmed HAŞıM's "Başım", Tevfik FiKRET's "Beyaz Yelken" and Yahya Kemal BEYATLI's "Rindlerin Akşamı" poems were chosen as examples. Two different printed booklets were created for these selected poems. In the control group booklet, only Ottoman spellings of poems were printed and students were asked to follow the lessons weekly on this booklet. For the experimental group, 
the selected poems were examined by two field experts and words that students would have difficulty in reading were determined. Later, qr-codes were created from qr-code-generator.com web address for free for these words using Ottoman texts, and the qr-codes and the words which are difficult to read were written below the poems in the experimental group booklet. In addition, the selected words are converted to 3D graphics with the help of Adobe PhotoShop and Adobe Illustrator programs. The graphics obtained are animated with Adobe Flash program. For four weeks, the course instructor taught the lesson. Figure-1 shows weekly procedures.

\begin{tabular}{|c|l|l|l|}
\hline Week & \multicolumn{1}{|c|}{ Control Group } & \multicolumn{1}{|c|}{ Experimental Group } \\
\hline $\mathbf{1}$ & $\begin{array}{l}\text { The academic achievement test prepared by the } \\
\text { researchers was used as a pre-test to determine the } \\
\text { academic success of the students. }\end{array}$ & $\begin{array}{l}\text { The academic achievement test prepared by the researchers } \\
\text { was used as a pre-test to determine the academic success of the } \\
\text { students. } \\
\text { Students were asked to download the Aurasma AR application } \\
\text { on their smartphones and they were informed how to use it. } \\
\text { Temporary smartphones were provided for 5 students who } \\
\text { didn't have any. }\end{array}$ \\
\hline $\mathbf{2}$ & $\begin{array}{l}\text { Ahmed Haşim's poem "Başım" was analyzed during the } \\
\text { lesson. }\end{array}$ & $\begin{array}{l}\text { Ahmed Haşim's poem "Başım" was analyzed during the } \\
\text { lesson. Students were asked to follow from the prepared } \\
\text { booklet. They were also asked to repeat at home using AR } \\
\text { technology. }\end{array}$ \\
\hline $\mathbf{4}$ & $\begin{array}{l}\text { Ahmed Haşim's poem "Başım" was analyzed during the } \\
\text { lesson. } \\
\text { Students are asked to follow from the prepared booklet. }\end{array}$ & $\begin{array}{l}\text { Ahmed Haşim's poem "Başim" was analyzed during the } \\
\text { lesson. Students were asked to follow from the prepared } \\
\text { booklet. They were also asked to repeat at home using AR } \\
\text { technology. }\end{array}$ \\
\hline $\begin{array}{l}\text { Ahmed Haşim's poem "Başım" was analyzed during the } \\
\text { lesson. } \\
\text { Students are asked to follow from the prepared booklet. }\end{array}$ & $\begin{array}{l}\text { Ahmed Haşim's poem "Başım" was analyzed during the } \\
\text { lesson. Students were asked to follow from the prepared } \\
\text { booklet. They were also asked to repeat at home using AR } \\
\text { technology. }\end{array}$ \\
\hline
\end{tabular}

Figure 1. Weekly procedures

\section{Application Samples}

Application samples word 1- aram
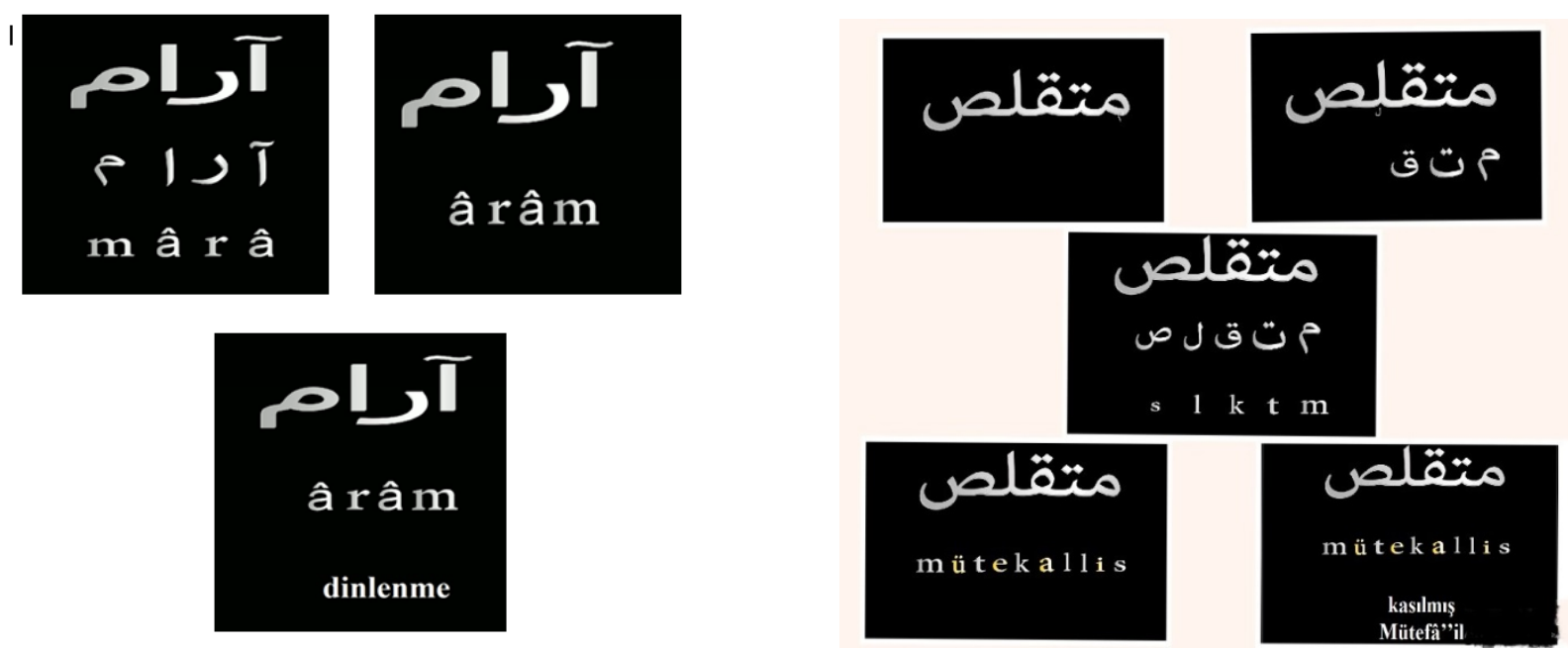
Application samples word 3- alayiş
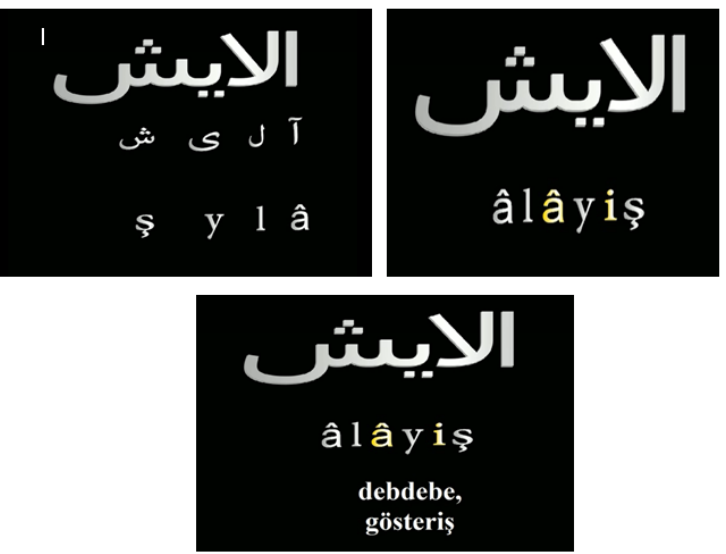

Application samples word 5- lahza
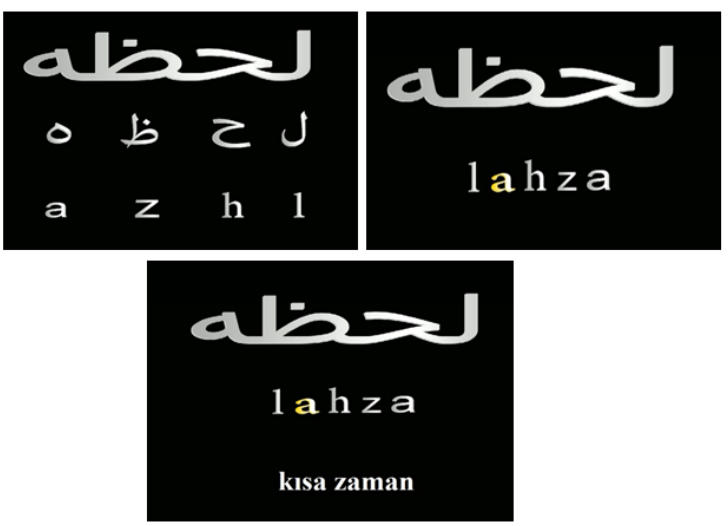

\section{Findings}

In order to answer the research question "What is the effect of the use of AR technology in the teaching of Ottoman words in students' academic achievement?", the academic achievement test prepared by the researchers was applied on the experimental and control groups as a pre-test before the implementation and the same test was applied on the experiment and control groups at the end of the 4-week implementation process as a post-test. The obtained data were analyzed with SPSS 15 analysis program and independent two samples were analyzed with t-test (Independent-Samples T-Test) analysis method. The findings obtained from the analysis of the data are indicated below.

\begin{tabular}{|l|c|c|c|c|c|c|c|}
\hline & N & Min & Max & Mean & ss & Skewness & Kurtosis \\
\hline Pre-test & 60 & 8.00 & 56.00 & 29 & 12.24 & .231 & -.666 \\
\hline Post-test & 60 & 24.0 & 92.0 & 56.4 & 15.17 & .151 & -.242 \\
\hline
\end{tabular}

When the values of the skewness and kurtosis of the data are examined, it is seen that it is between -1 and 1 , which is
Application samples word 4- ifrit

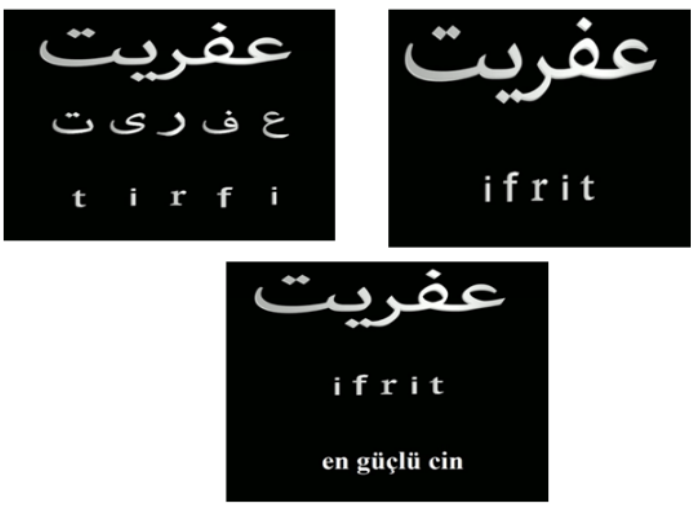

Application samples word 6- muadil
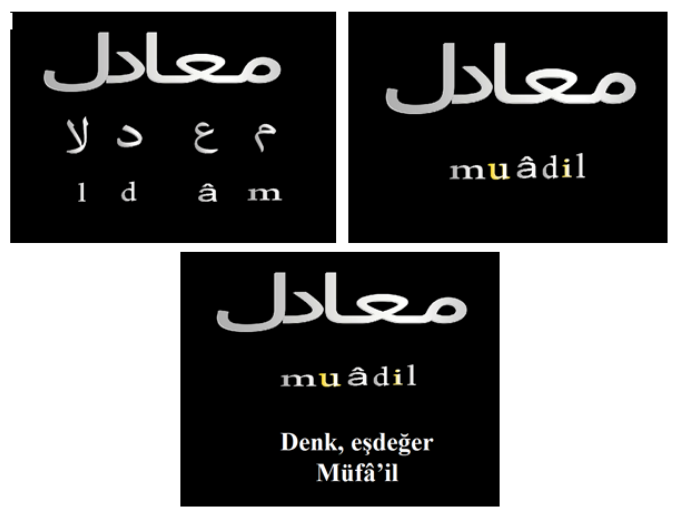

within acceptable limits.

\begin{tabular}{|c|c|c|c|}
\hline \multirow{2}{*}{} & \multicolumn{3}{|c|}{ Shapiro-Wilk } \\
\cline { 2 - 4 } & Statistic & df & Sig. \\
\hline Pre-test & .089 & 60 & .098 \\
\hline Post-test & .077 & 60 & .701 \\
\hline
\end{tabular}

The Shapiro-Wilk test revealed that the distribution was normal. Indeed, the $p$ value of each variable were determined to be above .05 .

\begin{tabular}{|c|c|c|c|c|c|}
\hline & $\mathbf{n}$ & $\mathbf{X}$ & s.s & t & P \\
\hline Pre-test & 60 & 29 & 12.2 & & \multirow{2}{*}{-16.7} \\
\cline { 1 - 4 } Post-test & 60 & 56.4 & 15.1 & & \\
\hline
\end{tabular}

According to the dependent $t$ test result which was done to determine the effect of the applied experimental process, the post-test scores differ significantly from the pre-test scores. It is seen that the average of the pre-test score of the students is $X=29$, and the post-test score average is 56.4 . Accordingly, it can be said that AR technology is effective in teaching Ottoman vocabulary teaching.

At the end of the research, the Material Motivation 
Questionnaire developed by Keller (1987) according to the ARCS motivational model was applied on the students of the experimental group to answer the research question "What is the motivation of the students of the experiment group for the material developed with AR technology?". As a result of the questionnaire, it can be said that the effect on the motivation of the students is high in positive direction.

As seen in Graph 1, when the average of the three dimensions of the material motivation questionnaire is examined, it is seen that the compliance-satisfaction dimension $(=4.17)$, the attention dimension $(=4.00)$ and the trust dimension $(=4.20)$ yield higher results. As a result, the developed materials have contributed positively to increasing the motivation of the learners, thus increasing both the desire to learn and the permanence of the learning. It is seen that the material used in the study is related to words they can encounter in their teaching life, and is effective in increasing student motivation.

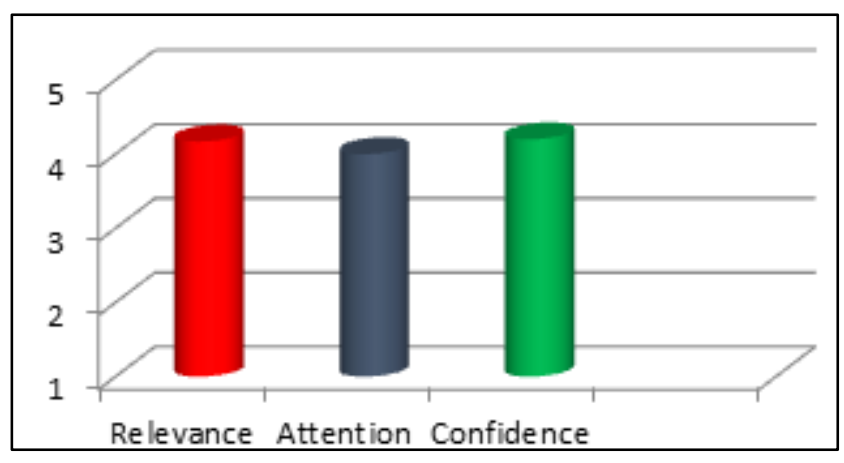

Graphic: 1. The results of the effects of the materials prepared with the augmented reality technology on the motivation of the students in terms of sub-dimensions

\section{Results and Discussion}

The purpose of this study is to measure the effect of the use of Augmented Reality (AR) practices on students' academic achievement and satisfaction levels in the Ottoman Turkish readings that learners are compelled to learn. According to the academic achievement test applied in this direction, the academic achievement of the students in the class taught with AR technology is higher than those in the class with classical method. Similar results are seen when the literature is examined. El Sayed, Zayed, and Sharawy (2011) have concluded that augmented reality learning cards have had a positive effect on the students towards the content. Juan, Loop and Abad (2010) have come to the conclusion that augmented reality in word teaching is beneficial. When the literature is reviewed, it is seen that there are various studies reaching the result that the attitude of the students is positive about the augmented reality applications (Küçük, Yılmaz, \& Göktaş, 2014; Shelton \& Hedley, 2004).

Another result of the study is that the motivation of the students towards the material used in the class taught with AR technology is high. In similar studies, it is seen that the motivation of students towards these materials is higher (Çakır, Solak, \& Tan, 2015; Pérez-López \& Contero, 2013; Mahadzi \& Phung, 2013). It has been seen that the insecurities and fears of the students towards the Ottoman Turkish lesson have decreased at the end of this study. The learners who comprehend that reading Ottoman words is easy through visuals can read other words with the system they learn from the visuals. The data obtained through this study is limited to the study group and the determined words. Therefore, AR technology can be further developed for Ottoman Turkish lesson, making learning more enjoyable and easier. Despite these limitations, it can be said that the model of the Ottoman word teaching developed with Augmented Reality Technology has a promising future about the permanence of information and increasing the demand for learning. AR technologies can be developed not only for Ottoman Turkish lessons but also for other Turkish Language Teaching lessons which the students have difficulty in learning.

\section{REFERENCES}

[1] Akbaş, M. F. (2011). Mobil Cihazlar Üzerinde 3 - Boyutlu Arttırılmış Gerçeklik Arayüz Yazılımı Geliştirme. Yüksek Lisans Tezi. İzmir: Ege Üniversitesi.

[2] Altunışık, R., Coşkun, R., Bayraktaroğlu, S., \& Yıldırım, E. (2010). Sosyal bilimlerde araştırma yöntemleri: SPSS uygulamall. Sakarya Yayıncilik.

[3] Aziz, K. A., Aziz, N. A., Yusof, A., \& Paul, A. (2012). Potential foProviding Augmented Reality Elements in Special Education via Cloud Computing. Procedia Engineering, 333-339.

[4] Azuma, R., Baillot, Y., Behringer, R., Feiner, S. K., Julier, S., \& MacIntyre, B. (2001). Recent advances in augmented reality. IEEE computer graphics and applications, 34-47.

[5] Bedük, A., \& Balcılar, H. (2009). Türkiye'nin bilgi Toplumu Olma Yolunda Bilgi Teknolojilerinden İnternetin Kullanımı: Muş İlindeki İnternet Kafe Kullanıcılarının Amaçları Üzerine Bir Araştırma. Sosyal Ekonomik Araştırmalar Dergisi, 1(16), 83-106.

[6] Bujak, K. R., Radu, I., Catrambone, R., MacIntyre, B., Zheng, R., \& Golubsk, G. (2013). A psychological perspective on augmented reality in the mathematics classroom. Computers \& Education, 68, 536-544.

[7] Çakır, R., Solak, E., \& Tan, S. S. (2015). Artırılmış gerçeklik teknolojisi ile ingilizce kelime öğretiminin öğrenci performansına etkisi. Gazi Ĕgitim Bilimleri Dergisi, 1(1), 45-58.

[8] Çetinkaya, H. H., \& Akçay, M. (2013). Eğitim Ortamlarında Arttırılmış Gerçeklik Uygulamaları. Akademik Bilişim 2013 - XV. Akademik Bilissim Konferansı Bildirileri (s. 1031-1035). Antalya: Akdeniz Üniversitesi. 
[9] Demirer, V., \& Erbaş, Ç. (2015). Mobil Artırılmış Gerçeklik Uygulamalarının İncelenmesi ve Eğitimsel Açıdan Değerlendirilmesi. Mersin Üniversitesi Eğitim Fakültesi Dergisi, 11(3), 802-814.

[10] Develi, H. (2009). Osmanlı'nın Dili. İstanbul: Kesit Yayınları.

[11] El Sayed, N. A., Zayed, H. H., \& Sharawy, M. I. (2011). ARSC: Augmented reality student card An augmented reality solution for the education field. Computers \& Education, 1045-1061.

[12] Gümüşkılıç, M. (2009). Türk Dili Ve Edebiyatı Bölümlerinde Osmanlı Türkçesi Eğitimi. 358-362.

[13] Juan, C. M., Llop, E., \& Abad, F. (2010). Learning Words Using Augmented Reality. Advanced Learning Technologies (ICALT), 2010 IEEE 10th International Conference on, (s. 422-426).

[14] Kaya, R. (2013). Tarih Öğretmen Adaylarının Lisans Eğitiminde Osmanlıca Öğretiminin İşlevselliği İle İlgili Görüşleri. Atatürk Üniversitesi Sosyal Bilimler Enstitüsü Dergisi, 17(2), 187-206.

[15] Klopfer, E., \& Squire, K. (2008). Environmental Detectives - the development of an augmented reality platform for environmental simulations. Educational Technology Research and Development, 56(2), 203-228.

[16] Kutu, H., \& Sözbilir, M. (2011). Öğretim Materyalleri Motivasyon Anketinin Türkçeye Uyarlanması: Güvenirlik ve Geçerlik Çalışması. Necatibey Eğitim Fakültesi Elektronik Fen ve Matematik Eğitimi Dergisi, 5(1), 292-312.

[17] Küçük, S., Yılmaz, R., \& Göktaş, Y. (2014). İngilizce Öğreniminde Artırılmış Gerçeklik: Öğrencilerin Başarı, Tutum ve Bilişsel Yük Düzeyleri. Eğitim ve Bilim, 39(176), 393-404.

[18] Liu, T.-Y., Tan, T.-H., \& Chu, Y.-L. (2010). QR Code and Augmented Reality-Supported Mobile English Learning System. Mobile Multimedia Processing(5960), 37-52.
[19] Mahadzi, N., \& Phung, L. (2013). The Use of Augmented Reality Pop-Up Book to Increase Motivation in English Language Learning For National Primary School. Journal of Research \& Method in Education, 26-38.

[20] Ortayl1, İ. (2014). Osmanlı Sarayında Hayat. Yitik Hazine Yayınlar1.

[21] Özkan, B., \& Şahbaz, N. K. (2011). Türkçe Öğretmeni Adaylarının Alan Derslerinin İşlevselliğine Yönelik Görüşleri. Sakarya Üniversitesi Eğitim Fakültesi Dergisi, 1(1), 32-43.

[22] Parlatır, İ. (2010). Açıklamalı Osmanlı Türkçesi Metinleri. Bursa: Ekin Yayınevi.

[23] Pérez-López, D., \& Contero, M. (2013). Delivering Educational Multimedia Contents through an Augmented Reality Application: A Case Study on its Impact on Knowledge Acquisition and Retention. The Turkish Online Journal of Educational Technology.

[24] Sarıkaya, M. (2015). Artırılmış Gerçeklik Uygulamalarının Öğrencilerin Akademik Başarıları, Kavram Yanılgıları Ve Derse Katılımlarına Etkisi. Doktora Tezi. Ankara: Gazi Üniversitesi.

[25] Shelton, B. E., \& Hedley, N. R. (2004). Exploring a Cognitive Basis for Learning Spatial Relationships with Augmented Reality. Technology, Instruction, Cognition and Learning, 323-357.

[26] Soylu, İ. (2015). Pratik Osmanlıca Dersleri, Dahi Adam.

[27] Timurtaş, F. (1979). Osmanlı Türkçesine Giriş, İstanbul, XVII.

[28] Tülü, M., \& Yılmaz, M. (2012). Iphone İle Artırılmış Gerçeklik Uygulamalarının Eğitim Alanında Kullanılması. Akademik Bilişim. Uşak: Ușak Üniversitesi.

[29] Wu, H.-K., Lee, S.-Y., Chang, H.-Y., \& Liang, J.-C. (2013). Current status, opportunities and challenges of augmented reality in education. Computers \& Education, 62, 41-49. 